\title{
When Do Managers Seek Private Equity Backing in Public-to-Private Transactions?
}

\author{
Jana P. Fidrmuc, Peter Roosenboom and Dick van Dijk
}

Version June 2009

\begin{tabular}{|l|l|}
\hline \multicolumn{2}{|l|}{ ERIM REPORT SERIES RESEARCH IN MANAGEMENT } \\
\hline ERIM Report Series reference number & ERS-2007-028-F\&A \\
\hline Publication & June 2009 \\
\hline Number of pages & 34 pages \\
\hline Persistent paper URL & http://hdl.handle.net/1765/10070 \\
\hline Email address corresponding author & djvandijk@ese.eur.nl \\
\hline Address & Erasmus Research Institute of Management (ERIM) \\
& RSM Erasmus University / Erasmus School of Economics \\
& Erasmus Universiteit Rotterdam \\
& P.O.Box 1738 \\
& 3000 DR Rotterdam, The Netherlands \\
& Phone: $\quad+31104081182$ \\
& Fax: $\quad+31104089640$ \\
& Email: info@erim.eur.nl \\
& Internet: $\quad$ www.erim.eur.nl \\
\hline
\end{tabular}

Bibliographic data and classifications of all the ERIM reports are also available on the ERIM website: www.erim.eur.nl 


\section{ERASMUS RESEARCH INSTITUTE OF MANAGEMENT}

\section{REPORT SERIES}

\section{RESEARCH IN MANAGEMENT}

\begin{tabular}{|l|l|}
\hline ABSTRACT AND KEYWORDS \\
\hline Abstract & $\begin{array}{l}\text { Over the last decade, the going private market has experienced a considerable boom in size and } \\
\text { also has become more interesting for private equity investors that are looking to partner with } \\
\text { incumbent management. This offers managers the choice to take the firm private themselves in } \\
\text { a traditional management buyout or to seek private equity backing. We propose that managers } \\
\text { decide for a management buyout without any involvement of private equity in case they are less } \\
\text { financially constrained: when their firms are undervalued, have high cash levels, are smaller and } \\
\text { less financially visible, and the managers own a large toehold. In contrast, managers invite } \\
\text { participation of private equity investors when they cannot complete the deal themselves: in firms } \\
\text { that are larger, have less cash and managers own a smaller fraction of the firm. Our analysis on } \\
\text { a sample of UK public-to-private transactions completed over the period 1997-2003 provides } \\
\text { results that are in line with these predictions. }\end{array}$ \\
\hline public-to-private transactions, corporate governance, private equity \\
\hline Free Keywords & $\begin{array}{l}\text { The ERIM Report Series is distributed through the following platforms: } \\
\text { Academic Repository at Erasmus University (DEAR), DEAR ERIM Series Portal } \\
\text { Social Science Research Network (SSRN), SSRN ERIM Series Webpage } \\
\text { Research Papers in Economics (REPEC), REPEC ERIM Series Webpage }\end{array}$ \\
\hline Classifications & $\begin{array}{l}\text { The electronic versions of the papers in the ERIM report Series contain bibliographic metadata } \\
\text { by the following classification systems: } \\
\text { Library of Congress Classification, (LCC) LCC Webpage } \\
\text { Journal of Economic Literature, (JEL), JEL Webpage } \\
\text { ACM Computing Classification System CCS Webpage } \\
\text { Inspec Classification scheme (ICS), ICS Webpage }\end{array}$ \\
\hline
\end{tabular}




\title{
When Do Managers Seek Private Equity Backing in Public-to-Private Transactions?*
}

\author{
Jana P. Fidrmuc ${ }^{\dagger}$ \\ Warwick Business School \\ Peter Roosenboom $\ddagger$ \\ RSM Erasmus University \\ Dick van Dijk ${ }^{\S}$ \\ Econometric Institute \\ Erasmus University Rotterdam
}

June 9, 2009

\begin{abstract}
Over the last decade, the going private market has experienced a considerable boom in size and also has become more interesting for private equity investors that are looking to partner with incumbent management. This offers managers the choice to take the firm private themselves in a traditional management buyout or to seek private equity backing. We propose that managers decide for a management buyout without any involvement of private equity in case they are less financially constrained: when their firms are undervalued, have high cash levels, are smaller and less financially visible, and the managers own a large toehold. In contrast, managers invite participation of private equity investors when they cannot complete the deal themselves: in firms that are larger, have less cash and managers own a smaller fraction of the firm. Our analysis on a sample of UK public-to-private transactions completed over the period 1997-2003 provides results that are in line with these predictions.
\end{abstract}

Keywords: Public-to-Private Transactions, Corporate Governance, Private Equity

JEL Classification: G32, G34

${ }^{*}$ We would like to thank participants of the Conference on Mergers and Acquisitions in Exeter, the ECB Conference on Asset Management, Private Equity Firms and International Capital Flows in Dublin, the 2007 Northern Finance Association annual meeting in Toronto, the 2008 European Finance Association annual meetings in Athens, and research seminars at the Warwick Business School, Manchester Business School, XFi Centre for Finance and Investment, University of Exeter, RSM Erasmus University and University of Antwerp. Also, we are grateful to Douglas Cumming, Ingolf Dittmann, Miguel Ferreira, Ian Garrett, Josh Lerner, Abe de Jong, Ian Tonks and Chendi Zhang for useful comments on an earlier draft of the paper and Shanaz Raja, Huiyan Xu and Hans van der Weijden for valuable research assistance.

${ }^{\dagger}$ Warwick Business School, University of Warwick, Coventry CV4 7AL, United Kingdom, Email: Jana.Fidrmuc@wbs.ac.uk (corresponding author)

${ }_{\ddagger}$ Department of Financial Management, RSM Erasmus University, P.O. Box 1738, NL-3000 DR Rotterdam, The Netherlands, e-mail: proosenboom@rsm.nl

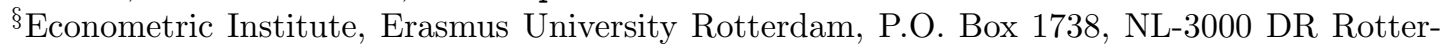
dam, The Netherlands, e-mail: djvandijk@ese.eur.nl 


\title{
When Do Managers Seek Private Equity Backing in Public-to-Private Transactions?
}

\begin{abstract}
Over the last decade, the going private market has experienced a considerable boom in size and also has become more interesting for private equity investors that are looking to partner with incumbent management. This offers managers the choice to take the firm private themselves in a traditional management buyout or to seek private equity backing. We propose that managers decide for a management buyout without any involvement of private equity in case they are less financially constrained: when their firms are undervalued, have high cash levels, are smaller and less financially visible, and the managers own a large toehold. In contrast, managers invite participation of private equity investors when they cannot complete the deal themselves: in firms that are larger, have less cash and managers own a smaller fraction of the firm. Our analysis on a sample of UK public-to-private transactions completed over the period 1997-2003 provides results that are in line with these predictions.
\end{abstract}

Keywords: Public-to-Private Transactions, Corporate Governance, Private Equity

JEL Classification: G32, G34 


\section{Introduction}

Around the world, the number of firms deciding for a public-to-private transaction has increased dramatically over the last decade. More and more companies consider going private because the reality of being a public company has fallen far short of the anticipated benefits. Another interesting development in the public-to-private market is that private equity investors have considerably increased their investment (Wright et al., 2006; Cumming et al., 2007, Bharath and Dittmar, 2009) and at the same time changed their strategy concerning their targets (Kiechel, 2007). In the 1980s, private equity investors often engaged in highly leveraged transactions many of which were seen as hostile by incumbent management (Lowenstein, 1985; Lehn and Poulsen, 1989). Nowadays, private equity investors are looking to partner with management. Incumbent managers typically remain with the company for some time after the private equity backed deal and, importantly, profit from their involvement in the deal through a generous compensation package (Wall Street Journal, 17 May 2007).

The new involvement of private equity investors in the public-to-private (PtP) market presents managers with the choice to take their firms private themselves or to obtain the backing of a private equity house. This paper is the first to examine this decision more closely. We compare MBOs, private equity backed deals and a control group of firms that remained publicly listed as three independent alternatives in a multinomial logistic regression. This helps us to explain the managers' choice between MBOs versus private equity backed deals in the public-to-private process.

The existing literature provides several reasons for why publicly listed firms may decide to go private. For example, managers may decide to take their firms private when they face a takeover threat (Lehn and Poulsen, 1989) or when their firm is undervalued. However, given that the private equity involvement in PtP deals is a relatively new phenomenon, the literature mostly does not investigate the decision of when managers seek private equity backing of the transaction. We put forward five non-mutually exclusive hypotheses all with a common theme that managers are less 
likely to rely on private equity backing when they are not financially constrained. In particular, we propose that managers do an MBO (rather than a private equity backed deal) when their firm is relatively more undervalued, is smaller, has high cash levels, managers own a large toehold and the firm is less financially visible. In contrast, managers invite participation of private equity investors and share control when they cannot do the deal themselves: in firms that are larger, have less cash at hand and managers own smaller share of the firm. In what follows, we describe the individual hypotheses in more detail. We should note here that as the focus of the paper is on the managers' choice, we take the interest of private equity investors in the deals as given. We argue that private equity investors are rational and would not be involved in a deal without expecting a positive return.

Undervaluation hypothesis: Survey evidence by Maupin et al. (1984) suggests that perceived undervaluation is one of the primary reasons for PtP transactions as it potentially limits management's ability to use benefits available to public companies as, for example, the accessibility of funds required to finance new investment projects or acquisitions as outside equity becomes more expensive for undervalued firms (Allen and Gale, 1999; Pagano et al., 1998). Undervaluation is also one of the main sources of shareholder wealth gains in PtP transactions (Renneboog et al., 2007). Moreover, undervalued firms are more likely to attract hostile takeover interest (Lehn and Poulsen, 1989) that may lead to managers losing their jobs (Lowenstein, 1985) which further increases managers' incentives for taking their firm private. Moreover, undervaluation is closely associated with financing constraints of the managers as the deal becomes cheaper. We therefore predict that managers are more likely to take their firms private without private equity backing when their firm is more undervalued.

Firm size hypothesis: An important factor that might drive the decision of whether to seek private equity backing when going private is firm size. However, most existing papers investigating the decision to go private have a control group that is matched based on industry and size (Lehn and Poulsen, 1989; Kieschnick, 1998; 
Weir et al., 2005) or do not include firm size as an explanatory variable (Halpern et al., 1999). We argue that as firm size gets larger the ability of managers to take the firm private themselves declines because of financial constraints. This increases the need for backing by private equity investors. We use a random control sample which allows us to test this firm size hypothesis.

Cash availability hypothesis: Most of the empirical evidence concerning going private transactions so far is based on Jensen's free cash flow hypothesis. Jensen (1986) proposes that debt-financed going private transactions may provide a solution to firms in cash-rich, slow growth and declining industries that are vulnerable to conflicts of interest between managers and shareholders over payout and investment policies. The empirical studies testing the free cash flow hypothesis in the context of going private transactions, however, provide mixed results (Lehn and Poulsen, 1989; Opler and Titman, 1993; Kieschnick, 1998; Renneboog et al., 2007). In this paper, we focus on a different aspect of cash-rich firms. We do not highlight the agency issues but rather propose that managers of cash-rich firms are less financially constrained to execute the transaction. They may see the potential of a leveraged transaction to gain control over their firms as they have the excess cash available to fund the transaction (Fox and Marcus, 1992) without the backing of a private equity investor.

Managerial toehold hypothesis: Halpern et al. (1999) and Elitzur et al. (1998) argue that managers who own a large stake in the company have more incentives to initiate a levered buyout. Managers with large stakes need to buy relatively fewer shares from other shareholders in order to become the sole owners of the firm. This makes it more financially feasible for them to go private without private equity investors obtaining an equity stake in the company.

Low visibility hypothesis: Bolton and von Thadden (1998) and Boot et al. (2006) highlight liquidity and low cost of capital as important benefits of public versus private ownership. Furthermore, thinly traded stocks have lower analyst coverage in general and are at risk of being neglected by investors when taking their investment 
decisions (Merton, 1987). Thus, firms that are not able to attract an adequate level of investor recognition have to bear the high cost of stock exchange listing while not taking enough advantage of the benefits of being a public company (Mehran and Peristiani, 2009) and are therefore more likely to go private. Moreover, illiquidity is often associated with high ownership concentration (Rubin, 2007) and therefore lower takeover probability. Also, illiquid stock is more vulnerable to greater mispricing (Mehran and Peristiani, 2009). Existing shareholders that wish to dispose of their thinly traded shares at an attractive price may therefore have little alternative than to agree to sell to management in a going private transaction. We conjecture that this improves the bargaining position of management and enables them to take the firm private at a cheaper price without the need for private equity backing.

Our results on a sample of 54 MBOs and 75 private equity backed buyouts in the UK over the period from 1997 to 2003 are in line with these predictions. Our tests when modeling the managers' decision indicate that managers make the decision to go private and the choice whether or not to partner up with a private equity investor at the same time. One can interpret this as managers seeing only one way of performing the going private transaction: they either opt to take their firm private through an MBO transaction or they seek private equity backing for their deal. The other option is not viable for them and therefore they make the two decisions (to go private and whether or not to seek private equity backing in doing so) at the same time. Moreover, we show that when managers face unwelcome takeover pressure, they decide to take their firm private to keep their job. In this decision, conditional on the firm characteristics, they have a choice to remain in full control (opt for an MBO) or share control with a private equity investor. Managers opt for an MBO when the deal is relatively cheap because of undervaluation of their firm stock, when they already own a large equity stake in the company or when their firms are less financially visible. They are also more likely to take their firm private themselves when the firm has substantial cash holdings that can be used for deal financing. This highlights a slightly different aspect of cash-rich firms than reported in prior studies 
(for example, Lehn and Poulsen, 1989 and Opler and Titman, 1993). Taken together, our results suggest that managers only invite private equity investors to back them when they are more financially constrained to complete the deal themselves. This is the case when firms have less cash and managers own a smaller fraction of the company. These results show that MBOs are different from private equity backed deals and so indicate that private equity involvement in the PtP market extends the possibilities for managers when considering a PtP transaction.

The rest of the paper is organized as follows. The next section describes the data set and provides the descriptive statistics. It also describes the regression models. Section 3 shows the results and Section 4 concludes.

\section{Data and methodology}

\subsection{Sample selection and descriptive statistics}

Our original sample consists of 221 non-financial firms that have gone private in the United Kingdom during the years 1997-2003. We identify these PtP transactions from the database of the Centre for Management Buyout Research (CMBOR). We do not have data for $9 \mathrm{PtP}$ firms and 32 firms operate in real estate. Therefore, we are left with 180 firms. Further, for all the PtP firms, we also obtain the offer documents accompanying the going private transaction from Thomson Research. We use these documents to determine management involvement and backing by private equity investors. First, we identify deals backed by a private equity house: we have a group of 83 private equity backed deals. In case the transaction is not backed by a private equity house we further examine whether any of the firm's executive directors are involved in the deal. This results in a group of 54 (pure) management buyouts. The remaining 43 transactions are backed by non-executive directors, wealthy families or institutional investors other than private equity houses. As this latter group is very heterogeneous and does not fit our research question, we drop it from our sample. In summary, we have 83 private equity backed deals and 54 MBOs.

In order to model the public-to-private decision, it is essential to establish who 
the decision maker is. In case of MBOs, it is clear that management is in control. But is this also the case for private equity backed deals? The offer documents show that 3 private equity backed deals are buy-and-build deals initiated by private equity investors. The purpose of these deals is to merge the target company within an existing portfolio company of the private equity investor, so we exclude these 3 firms from the data set. Further, out of the 80 private equity backed firms, one deal is hostile and 14 bids are contested. The hostile bid results in ousting of the incumbent management. However, none of the 14 contested bids results in managerial change. In total, management is replaced only in 5 deals including the hostile offer. These are usually cases when firms are offered for sale due to insolvency. In further 3 cases, the deal results in a partial managerial change with prior board agreement. To be fully consistent with our model where we assume that the management is in control, we drop the 5 transactions with managerial change from our sample. We end up with $54 \mathrm{MBO}$ deals and 75 private equity backed deals.

To run the multinomial logit, we need a group of control firms that remained publicly listed. We opt for a random sample of control firms. In each year of the sample period of 1997-2003 we randomly select 200 control firms from a population of around 1200 companies that continue to be publicly traded in a given year. The sampling procedure allows for a control firm to be included in the sample more than once. In total, we collect data on 1400 control firm-years that cover 960 different control firms. For both the PtP firms and control firms, we get market prices from Datastream, financial statement data from Worldscope, and hand-collect ownership structure and board composition information from Price Waterhouse Coopers' Corporate Register.

In the going private literature it is common to use a matched control sample of firms that remained public. Firm size and industry classification are the most commonly used matching criteria. In general, the sampling method (a random sample versus a matched sample) does not pose any advantages or disadvantages except for the case where the characteristics used for the matching process are important 
determinants of the going private process (Halpern et al., 1999). We prefer random to matched sampling because we believe that firm size is a relevant factor influencing the decision to take the firm private with versus without private equity backing. Moreover, random sampling results in a larger data set. Nevertheless, we employ a matched sample (based on industry and size) as a robustness check.

Table 1 shows our variable definitions and Table 2 shows summary statistics for the random and matched control non-PtP firms, MBOs, and private equity backed deals, respectively. All variables are trimmed at the 1st and 99th percentiles, except the ownership and illiquidity variables. We test for differences in means and medians among our random control group, MBOs and private equity backed deals. We use a t-test for equal means allowing for unequal variances and a Mann-Whitney U-test for equal medians. Below we discuss the statistically significant differences in mean and median first between non-PtP firms versus MBOs and private equity backed deals. Then we turn to significant differences between the two PtP groups.

\section{- insert Tables 1 and 2 about here -}

Columns 5 and 6 in Table 2 report p-values for the differences in means and medians between control firms (random sample of non-PtP firms) versus MBOs and private equity backed firms, respectively. PtP firms, both MBOs and private equity backed, are valued less than control firms as indicated by their lower market to book ratios and also experience more takeover rumours. MBO firms are smaller, their shares are traded less actively than the shares of the control firms and are followed by fewer analysts. Moreover, the MBO firms have higher equity stakes held by executive directors and smaller financial institution ownership than the control firms. Private equity backed firms, in contrast, have higher ownership by financial institutions relative to control firms but their ownership concentration is lower. Private equity backed firms have less cash but at the same time are more profitable and pay higher dividends relative to control firms. MBOs pay lower tax.

Turning to the differences between the two groups of PtP firms (Column 7 of Table 2), we observe that private equity backed deals are larger and more profitable 
relative to MBO deals. They pay higher dividends and tax. Their market to book ratio is higher indicating that they are less undervalued than the MBO deals. Private equity backed deals also enjoy more financial visibility as they are followed by more analysts and their shares are more actively traded. Ownership structure of the two groups is also significantly different: private equity backed firms have significantly lower executive ownership and higher ownership by financial institutions and their pre-transaction ownership concentration is lower. Finally, private equity backed firms have less cash on hand but higher cash flows. This seems to be a contradiction. However, DeAngelo and DeAngelo (2006) argue that the firm's current cash flow is not a suitable measure of managerial opportunism as it does not reflect the stock of resources at manager's disposal. What matters is managers access to the stock of liquid assets at all points in time which is better reflected in the firm's cash and marketable securities. In fact, free cash flow is highly correlated with the firm's profitability which indicates that it is restricted to affect managerial incentives only at a distribution point (DeAngelo and DeAngelo, 2006) and, thus, it may not be enough to encompass all resources at managers disposal and therefore is not able to generate empirically valid predictions. This suggests that the firm's cash level is

a more suitable proxy for free cash at the disposal and discretion of the managers. Table 2 reports that private equity backed deals have less cash on their balance sheet than MBOs.

\subsection{Multinomial logistic model}

In the empirical analysis we employ multinomial logistic regression (MNLR) models to examine the differences and similarities between traditional management buyouts and private equity backed deals. The model includes also a (random or matched) control group of firms that remained listed, to address the question why the decision to undertake either of the two types of going-private transaction is made. So, we divide our sample of UK firms into three different groups: (1) management buyouts, (2) private equity backed PtP deals, and (3) non-PtPs. We denote the observed 
group for firm $i$ by the variable $y_{i}$, which can take the discrete values $1,2, \ldots, M$, where $M=3$ in our case. In the MNLR model the probability that firm $i$ will belong to group $m$, conditional on the $(k \times 1)$ vector of explanatory variables $x_{i}$ consisting of a constant and firm characteristics, is given by

$$
P\left[y_{i}=m \mid x_{i}\right]=\frac{\exp \left(\beta_{m}^{\prime} x_{i}\right)}{\sum_{l=1}^{M} \exp \left(\beta_{l}^{\prime} x_{i}\right)}, \quad \text { for } m=1, \ldots, M .
$$

For identification purposes, we set the coefficients for the non-PtP group of firms equal to 0 , that is $\beta_{3}=0$.

The effects of the firm characteristics $x_{i}$ on the probabilities that a firm engages in the different types of going-private deals is a nonlinear function of the model parameters $\beta_{m}$, such that interpretation of these parameters is not straightforward. For interpretation of the model, it is useful to consider the log-odds ratio of group $m$ versus group $l$, defined as

$$
\log \left(\frac{P\left[y_{i}=m \mid x_{i}\right]}{P\left[y_{i}=l \mid x_{i}\right]}\right)=x_{i}^{\prime}\left(\beta_{m}-\beta_{l}\right) .
$$

This shows that firms with a larger value for $x_{i, j}$ more likely belongs to group $m$ than to group $l$ if $\left(\beta_{m, j}-\beta_{l, j}\right)>0$, where $x_{i, j}$ indicates the $j$-th element of $x_{i}$, and $\beta_{m, j}$ and $\beta_{l, j}$ are the corresponding coefficients. Note that this does not necessarily imply that the probability that firm $i$ belongs to group $m$ increases with $x_{i, j}$, as the the odds ratios of group $m$ versus the other categories also change. The net marginal effect of a change in $x_{i, j}$ on the group probability follows from the partial derivative of $P\left[y_{i}=m \mid x_{i}\right]$ with respect to $x_{i, j}$, which is given by

$$
\frac{\partial P\left[y_{i}=m \mid x_{i}\right]}{\partial x_{i, j}}=P\left[y_{i}=m \mid x_{i}\right]\left(\beta_{m, j}-\sum_{l=1}^{M} \beta_{l, j} P\left[y_{i}=l \mid x_{i}\right]\right) .
$$

The sign of this derivative depends on the sign of the term between brackets, which may be positive or negative depending on the value of $x_{i}$. Hence, the sign of the marginal effect of $x_{i, j}$ on $P\left[y_{i}=m \mid x_{i}\right]$ will not always correspond with the sign of the coefficient $\beta_{m, j}$. Also note that the marginal effect depends on the values of the other explanatory variables in $x_{i}$, denoted as $x_{i,-j}$. In order to obtain a clear view on 
the effect of the variable of interest $x_{i, j}$ one should therefore consider $\frac{\partial P\left[y_{i}=m \mid x_{i, j}\right]}{\partial x_{i, j}}=$ $\int_{x_{i,-j}} \frac{\partial P\left[y_{i}=m \mid x_{i}\right]}{\partial x_{i}} d x_{i,-j}$, integrating out the effects of these other explanatory variables. In practice this can be done by averaging (3) across all realizations of $x_{i,-j}$ in the sample for each value of $x_{i, j}$.

An important assumption underlying the MNLR model in (1) is independence of irrelevant alternatives (IIA), meaning to say that the odds ratio of remaining public versus going private through an MBO does not depend on the inclusion of the private equity backed PtP deals, which can also be seen from (2). In economic terms, this comes down to the assumption that managers make the decision to go private and the choice whether or not to partner up with a private equity investor at the same time. Put differently, taking their firm private through an MBO transaction or by seeking private equity backing are not considered as competing options for management. We can examine the validity of this hypothesis by testing the IIA assumption, which is done by means of the specification test developed by Hausman and McFadden $(1984))$.

The MNLR model also provides an easy way to test whether the characteristics of firms involved in MBOs and private equity backed PtP transactions are significantly different. Note that such heterogeneity implies that certain firm characteristics such as analyst coverage and management ownership affect the relative probabilities of a firm belonging to the different groups. In other words, in the MNLR model the coefficients $\beta_{m, j}$ should differ across the MBO and private equity backed groups $m=$ 1 and 2 . For an individual variable, $x_{i, j}$ say, the null hypothesis of no heterogeneity across groups $m$ and $l$ can easily be tested by means of a likelihood ratio test of the restriction $\beta_{m, j}=\beta_{l, j}$. The same holds for a given sub-set of the explanatory variables included in the model. Testing whether there is no heterogeneity at all is slightly more complicated, and effectively boils down to testing whether the two groups can be combined into one. This is done by means of the likelihood ratio test developed by Cramer and Ridder (1991).

Finally, we mention an important caveat in the maximum likelihood estimation 
of the coefficients in the MNLR model in (1). Our overall data set is not a random sample from the population of all firms. In particular, we include all known MBOs and private equity backed deals during the period 1997-2003, but only a selected number of firms is included in the control group. In the case of random sampling, for each year in our sample period we only include 200 of the firms that remain listed, which in total equal 1200, on average. For the matched sampling case, the inclusion of control firms obviously is even more selective. This implies that in both cases PtP firms are considerably overrepresented in our sample compared to the underlying population of firms. Not accounting for this selective sampling would lead to biased estimates of the intercepts and incorrect standard errors for all estimated coefficients; see Kieschnick (1998) and Fok and Franses (2002) for detailed analysis of selective sampling in the context of binary and ordered logit models, respectively. The problem can be remedied by defining modified probabilities as

$$
\tilde{P}\left[y_{i}=m \mid x_{i}\right]=\frac{\gamma_{m} P\left[y_{i}=m \mid x_{i}\right]}{\sum_{l=1}^{M} \gamma_{l} P\left[y_{i}=l \mid x_{i}\right]}, \quad \text { for } m=1, \ldots, M,
$$

where $\gamma_{m}$ is the fraction of firms in group $m$ that is included in the sample. Hence, in our case $\gamma_{1}=\gamma_{2}=1$ while in the random sampling case, for example, we have $\gamma_{3}=1 / 6$. The correct likelihood function, which is used for parameter estimation then makes use of these corrected probabilities.

\section{Results}

Table 3 reports the multinomial logit estimation results with randomly selected and matched control group of non-PtP firms in Panel A and Panel B, respectively. To account for industry and time effects, all regressors are taken in deviation from industry median and annual median values. Our model treats the non-PtP control firms as the omitted category. Hence, Table 3 reports two sets of coefficients: for MBO deals and for private equity backed deals. These coefficients show how the explanatory variables affect the probability of going private through the particular type of transaction relative to the probability of remaining public. The last column 
in both panels shows p-values for a likelihood ratio test of equal parameters between MBOs and private equity backed deals. Thus, it shows significance of coefficient differences between the two going private types. Finally, the last two lines of the two panels show p-values for the likelihood ratio test of Cramer and Ridder (1991) that all parameters except the intercept are equal for the corresponding two groups and the independence of irrelevant alternatives test, respectively.

\section{- insert Table 3 about here -}

The independence of irrelevant alternatives test reported in the last row (for both random sample and matched control firms) confirms that a multinomial logit model fits our data better than a nested logit model. This also shows that the choice of the particular type of going private deal, whether the deal is indeed supported by a private equity house or is fully led by the management, is independent. Thus, the decision to go private is made at the same time as the decision about the type of the deal. Moreover, the no heterogeneity test of Cramer and Ridder (1991) suggests that the two going private groups have different deal characteristics from the non-PtP firms as well as from each other. The remainder of this section shows how the two groups of PtP firms differ and why they go private.

\subsection{Takeover threat and undervaluation}

To avoid a credible takeover threat is an important motivation for a manager to decide to take his firm private. The results in Table 3 strongly confirm this conjecture. The positive and significant (at the one percent level) coefficients for rumours show that both PtP types experience relatively high takeover interest in the period before the transaction compared to the control group. The difference in coefficients between the two groups of PtP firms is insignificant. Further, Table 3, Panel A suggests that perceived undervaluation plays an important role for PtP firms. The coefficient for the market to book ratio is significantly negative for both types of PtP deals showing that both MBOs and private equity backed deals are on average 
undervalued relative to the firms that remain public. The coefficient for MBOs is more negative relative to private equity backed deals, but the difference is not statistically significant. The results in Panel B with matched control firms are slightly different as only the coefficient for MBOs is negative and significant and the difference between MBOs and private equity backed firms is statistically different at the one percent level. We also include sales growth over the last three years and return on assets as explanatory variables to control for growth prospects. The two variables are not statistically significant.

We perform two additional sensitivity checks to support our undervaluation hypothesis. First, we use the Rhodes-Kropf et al. (2005) market to book decomposition into three components: the firm-specific error; sector error and long-run value to book. ${ }^{1}$ The results with the three components are reported in Table 4 . The first two components refer to undervaluation: the firm-specific error should reflect deviations of firm value from short-run industry pricing and therefore measure firm-specific undervaluation relative to other peers in the industry at that point in time. The sector error should reflect sector-wide, short-run deviations from long-run pricing of all firms in the same industry and therefore measures short-run undervaluation of the whole industry. The third component separates out long-run growth prospects of the firm. Both coefficients for firm-specific error in Table 4 are significantly negative at the one percent level and not statistically different from each other. At the same time, the coefficient for the sector error is negative and statistically significant at the ten percent level for MBOs whereas it is positive and insignificant for private equity backed deals. The difference between the two coefficients is significant at the ten percent level. This indicates that both MBOs and private equity backed firms are short-run undervalued relative to their industry peers, but MBOs are, on top of this, in undervalued industries. Moreover, the effect of the third component indicates that MBOs are low long-run value to book firms whereas private equity backed deals are

\footnotetext{
${ }^{1}$ For the decomposition, we use Rhodes-Kropf et al. (2005) Model 3 (on page 577) with industries matching our previous specification in Table 3.
} 
not. Thus, the market to book decomposition indicates that MBOs versus private equity backed PtP firms are different both with respect to undervaluation as well as long-run growth prospects. This is in line with the overall story that managers seeking private equity backing are more financially constrained.

\section{- insert Table 4 about here -}

Second, we use insider trading patterns in our firms to support the view that our results on the market to book ratio pick up the effect of private information. If undervaluation is indeed one of the reasons for going private, we could expect that managers trading in advance of the event may partially reveal the importance of that information. In fact, Harlow and Howe (1993) document significant increase in trading by insiders prior to the announcement of US management-led buyouts over the period from 1980 to 1989. They show, however, that this abnormal pattern arises not from increases in purchases but from abnormally low levels of stock sales. Harlow and Howe (1993) argue that this passive insider trading strategy is preferred by managers as it reduces their liability risk. In line with this existing evidence, our management sponsored deals should experience abnormally low insider sales relative to the private equity backed deals and non-PtP firms. In order to show this, Table 4 includes two dummy variables that reflect the insider purchase and sale patterns of executive directors of firms in our sample. In particular, the executive director purchase (sale) dummy is set to one in case an executive director purchased (sold) some shares of his/her own firm in the calendar year prior to the announcement and set to zero otherwise. Our results confirm that managers of MBOs tend to sell their shares significantly less often than their counterparts in non-PtP firms and private equity backed deals. We do not see any significant differences for the purchase patterns. Thus, our results are in line with Harlow and Howe (1993) and support our conclusion that firm undervaluation is more important in motivating MBOs versus private equity backed deals. 


\subsection{Firm size, cash availability and managerial toehold}

We can explore the effect of size only relative to the random sample of control nonPtP firms (in Panel A of Table 3) as size is one of the matching requirements in Panel B. The coefficient estimates for size (log of total book value of assets) are not in line with our hypothesis that buying smaller firms implies looser financial constraints and therefore should be associated with MBOs. In fact, the two coefficients have opposite signs and both are insignificant. Inspecting the correlation matrix, however, we find high positive correlation between size and thin trading. This means that inclusion of the thin trading variable in the regression strongly impacts the coefficients for size. As both variables are important and their correlation does not affect other coefficients, we opt to include both total assets and thin trading in our main model. However, Table 5 reports a set of regression results without thin trading. Both of the size coefficients are now negative and statistically significant at conventional levels. Equality of the two coefficients, however cannot be rejected. This suggests that both MBOs and private equity backed PtP firms are smaller relative to the control sample.

\section{- insert Table 5 about here -}

Free cash at discretion of managers is the next characteristic that may motivate a PtP deal and potentially distinguish MBOs from private equity backed deals. We conjecture that more cash rich firms are more likely to go private without private equity backing because they have the means of doing so. The coefficients for our cash variable in Panel A of Table 3 are positive for MBOs and negative for private equity backed deals. Even though only the latter coefficient is significant at the ten percent level, they are statistically different from each other at the five percent level. In Panel B the coefficient for MBOs is statistically significant at the ten percent level and the difference is significant at the one percent level. Thus, our results suggest a sharp difference in the effect of cash levels: MBOs seem to be cash rich while private equity backed deals suffer very low cash levels. We control for 
payout ratio and leverage as cash, dividend and capital-structure decisions may be interconnected (DeAngelo and DeAngelo, 2006). Table 3 shows that neither payout ratio nor leverage are statistically significant at conventional levels.

An alternative interpretation of the low cash levels of private equity backed deals might be firm insolvency and inability to pay interest payments. To account for this possibility, we check average interest coverage across deciles of cash levels of the private equity backed firms. This exercise, however, shows that interest coverage is not related to cash level of the private equity backed deals. Including interest coverage in the regression does not result in a significant coefficient for the private equity backed deals nor does this affect the cash coefficient. ${ }^{2}$

As a sensitivity check we also estimate excess cash, recently proposed to proxy for corporate cash reserves (Opler et al., 1999 and Dittmar and Mahrt-Smith, 2007). We estimate a cash regression that should determine normal cash levels used to cover companies liquidity needs. ${ }^{3}$ Residuals of this regression then measure cash reserves held in excess of those needed for operations and investments. These resources are most probably used at managers' discretion (Dittmar and Mahrt-Smith, 2007). In Table 6, we partition the cash variable from Panel A of Table 3 into two separate variables: normal cash and excess cash representing the fitted values and residuals from the cash regression, respectively. The results for excess cash are equally strong despite fewer observations due to data availability for the cash regression. The regression in Table 6 includes also free cash flow and shows that free cash flow does not affect the decision to do a public-to-private deal.

\section{- insert Table 6 about here -}

\footnotetext{
${ }^{2}$ All results are available upon request.

${ }^{3}$ Following Opler et al. (1999) and Dittmar and Mahrt-Smith (2007) we regress the natural logarithm of cash over net assets (total assets minus cash and marketable securities) on the natural logarithm of net assets, market to book adjusted for net assets, net working capital over net assets, capital expenditures over net assets, $R \& D$ over net assets, free cash flow over net assets, leverage and a dividend dummy. All variables are industry and time adjusted. Due to missing data, we are able to obtain only 1,437 observations for excess cash compared to 1,579 observations in our full sample.
} 
Our next deal characteristic concerns pre-transaction ownership. Table 3 shows that the coefficient for executive ownership in MBO deals is positive and significant at the one percent level while the coefficient is not significant for private equity backed firms. The difference in coefficients between the two types of PtP firms is significant at the one percent level. This shows that high executive ownership increases the probability of an MBO relative to both non-PtP firms and private equity backed firms. We also check for ownership concentration measured by the Herfindahl index. The results suggest that ownership concentration is significantly higher for MBOs and lower for the private equity backed deals which is in line with higher executive ownership for MBOs. ${ }^{4}$

\subsection{Financial visibility}

Finally, we turn to the effect of financial visibility. The results in Table 3 show that low financial visibility increases chances of MBOs whereas it is not important for private equity backed deals. In Panel $\mathrm{A}$, the coefficient for the number of analysts following a firm is negative and significant at the ten percent level for MBOs whereas it is positive but not significant for private equity backed deals. Importantly, the two coefficients are significantly different at the five percent level indicating that firms that decide for an MBO suffer significantly lower financial visibility relative to private equity backed deals. Analyst following is, however, not significant in Panel B of Table 3 with the matched sample. This is perhaps due to the smaller number of observations. The results for thin trading (high fraction of zero returns) are even stronger. Thin trading is associated with higher probability of an MBO relative to both the non-PtP control firms as well as private equity backed deals (both statistically significant at the one percent level).

An important issue is that our results for financial visibility may be driven by size as the two variables are closely related (O'Brien and Bhushan, 1990). Put differently, it may be the case that our PtP firms, especially the MBO deals, are relatively small

\footnotetext{
${ }^{4}$ All results are available upon request.
} 
and then of course, they are thinly traded and not followed intensively by analysts. Even though we implicitly control for firm size in the matched sample and still get strong results for thin trading, to make a stronger case for our visibility hypothesis, we check distribution of PtP firms across the size spectrum of our sample and relate analyst coverage and thin trading for PtP versus non-PtP firms within all size groups. Table 7 shows mean values of analyst coverage and thin trading measures as well as frequencies of private equity backed and management sponsored deals across size deciles (measured by total assets). The table shows that low analyst coverage and thin trading are indeed negatively correlated with size. However, it also shows that even though the going private firms are significantly underrepresented among the smallest and largest firms, PtP firms are relatively evenly spread across the remaining 8 middle size deciles. Thus, this indicates that the association between financial visibility and probability of going private is not due to the size effect.

\section{- insert Tables 7 and 8 about here -}

To push this argument further, Table 8 reports the same statistics by size deciles separately for the non-PtP random sample firms, private equity backed firms, and MBOs, respectively. Panel A, reporting the means for the non-PtP firms, reinforces the overall trend that analyst coverage is increasing and thin trading falling with size. The same pattern is reflected in Panel B for private equity backed firms. Overall, private equity backed deals seem to be slightly less frequently traded but equally monitored by analysts relative to the non-PtP firms across all size deciles. In contrast, Panel $\mathrm{C}$ shows sharply lower analyst coverage and thinner trading for MBOs relative to the non-PtP firms across all size deciles. Thus, this shows that the management sponsored deals suffer lower financial visibility relative to both private equity backed deals as well as the non-PtP deals. Moreover, this effect is clearly present across all size deciles and, thus, is not driven by size.

Another closely related argument is that the going private firms might be more likely to be listed on the Alternative Investment Market (AIM) with lower listing 
requirements which in turn would drive the visibility result. The last column in Tables 7 and 8 reports AIM listing frequency among our firms and does not detect any significant trend. Also, in an unreported regression, we include an AIM dummy as an additional regressor. As the coefficients are not significant and the other results remain unaffected we conclude that AIM listing does not drive our results. Overall, our results show that management sponsored deals suffer both lower analyst coverage and are less frequently traded and therefore have less reasons to remain publicly listed whereas this is not the case for the private equity backed deals. Considering financial visibility, MBOs and private equity backed firms are significantly different.

\section{Conclusions}

This paper is the first to examine the managerial decision to seek private equity backing in taking the firm private. Our analysis is conditioned on management taking the going private decision and keeping their jobs afterwards. Our main findings are threefold. The first important insight is that managers decide about going private and whether or not to involve private equity investors as part of the deal simultaneously. This indicates that the alternative way of going private is not viable in their situation. Second, we show that PtP transactions are often triggered by a takeover threat which highlights the managerial desire to keep their job. We also find that both types of PtP firms are smaller relative to the control sample of firms that remained listed on the stock exchange. Finally, our analysis reveals that managers prefer to take their firms private themselves without the backing of private equity house if they are less financially constrained. This allows them to remain in full control instead of sharing control with a private equity investor and reap the benefits of the deal for themselves. In particular, our analysis shows that managers decide to take their firm private when it is relatively cheaper because of undervaluation of their firms stock, when they already own a large equity stake in the company or when their firms are less financially visible in sense that their stock is thinly traded and they are followed by fewer analysts. Managers are also more 
likely to take their firm private when the firm has substantial cash holdings that can be used for deal financing. Managers tend to invite private equity investors to back them when they are more financially constrained. This is the case when their firms have less cash and managers own a smaller fraction of the company. So, our results show that the two types of PtP firms have significantly different characteristics. We interpret this result as indicating that private equity involvement in the PtP market extends the possibilities for managers when considering a PtP transaction. 


\section{References}

Allen, F., and D. Gale, 1999, "Diversity of Opinion and Financing of New Technologies," Journal of Financial Intermediation, 8, 68-89.

Bharath, S.T. and A.K. Dittmar, 2009, "Why Do Firms Use Private Equity to Opt out of Public Markets?". Review of Financial Studies, forthcoming.

Bolton, P., and E.-L. von Thadden, 1998, "Blocks, Liquidity, and Corporate Control," Journal of Finance, 53, 1-25.

Boot, A.W.A., R. Gopalan, and A.V. Thakor, 2006, "The Entrepreneurs chose between Private and Public Ownership," Journal of Finance, 61, 803-836.

Cramer, J.S. and G. Ridder, 1991, "Pooling States in the Multinomial Logit Model," Journal of Econometrics, 47, 267-272.

Cumming, D., D.S. Siegel and M. Wright, 2007, "Private Equity, Leveraged Buyouts and Governance," Journal of Corporate Finance, 13, 439-460.

DeAngelo, H. and L. DeAngelo, 2006, "Capital Structure, Payout Policy, and Financial Flexibility," USC Marshall School of Business Working Paper \#02/06.

Dittmar, A. and J. Mahrt-Smith, 2007, "Corporate Governance and the Value of Cash Holdings," Journal of Financial Economics, 83, 599-634.

Elitzur, R., P. Halpern, R. Kieschnick, and W. Rotenberg, 1998, "Managerial Incentives and the Structure of Management Buyouts," Journal of Economic Behavior and Organization, 36, 347-367.

Fok, D., and P.H. Franses, 2002, "Ordered Logit Analysis for Selectively Sampled Data," Computational Statistics and Data Analysis, 40, 477-497.

Fox, I. and A. Marcus, 1992, "The Causes and Consequences of Leveraged Management Buyouts," Academy of Management Review, 17, 62-85.

Halpern, P., R. Kieschnick, and W. Rotenberg, 1999, "On the Heterogeneity of Leveraged Going Private Transactions," Review of Financial Studies, 12, 281-309.

Harlow, W.V. and J.S. Howe, 1993, "Leveraged Buyout and Insider Nontrading," Financial Management, 22, 109-118.

Hausman, J. and D. McFadden, 1984, "Specification Tests for the Multinomial Logit Model," Econometrica, 52, 1219-1240.

Jensen, M., 1986, "Agency Costs of Free Cash Flows, Corporate Finance and Takeovers," American Economic Review, 76, 323-329.

Kiechel, W., 2007, "Private Equity's Long View," Harvard Business Review 85 (7/8), 18-19.

Kieschnick, R., 1998, "Free Cash Flow and Stockholder Gains in Going Private Transactions Revisited," Journal of Business Finance and Accounting, 25, 187-202.

Lehn, K., and A. Poulsen, 1989, "Free cash Flow and Stockholder Gains in Going Private Transactions," Journal of Finance, 44, 771-787. 
Lowenstein, L., 1985, "Management buyouts," Columbia Law Review, 85, 730-784.

Maupin, R.J., C.H. Bidwell, and A.K. Ortegren, 1984, "An Empirical Investigation of the Characteristics of Publicly-Quoted Corporations Which Change to Closely-Held Ownership Through Management Buyouts," Journal of Business Finance and Accounting, $11,435-450$.

Mehran, H. and S. Peristiani, 2009, "Financial Visibility and the Decision to Go Private," Review of Financial Studies, forthcoming.

Merton, R.C., 1987, "A Simple Model of Capital Market Equilibrium with Incomplete Information," Journal of Finance, 42, 483-510.

O'Brien, P. and R. Bhushan, 1990, "Analyst Following and Institutional Ownership," Journal of Accounting Research, 28, 55-65.

Opler, T., and S. Titman, 1993, "The Determinants of Leveraged Buyout Activity: Free Cash Flow vs. Financial Distress Costs," Journal of Finance 48, 1985-1999.

Opler, T., L. Pinkowitz, R. Stulz, and R. Williamson, 1999, "The Determinants and Implications of Cash Holdings," Journal of Financial Economics, 52, 3-46.

Pagano, M., F. Panetta, and L. Zingales, 1998, "Why Do Companies Go Public? An Empirical Analysis," Journal of Finance, 53, 27-64.

Renneboog, L., T. Simons and M. Wright, 2007, "Why Do Public Firms Go Private in the UK? The Impact of Private Equity Investors, Incentive Realignment and Undervaluation, Journal of Corporate Finance, 13, 591-628.

Rhodes-Kropf, M., D.T. Robinson, and S. Viswanathan, 2005, Valuation Waves and Merger Activity: The Empirical evidence, Journal of Financial Economics, 77, 561603.

Rubin, A., 2007, "Ownership Level, Ownership Concentration and Liquidity," Journal of Financial Markets, 10, 219-248.

Weir, C., D. Laing, and M. Wright, 2005, "Incentive Effects, Monitoring Mechanisms and the Market for Corporate Control: An Analysis of Factors Affecting Public to Private Transactions in the UK," Journal of Business Finance and Accounting, 32, 909-943.

Wright, M., L. Renneboog, L. Scholes, and T. Simons, 2006, "Management Buyouts in the UK and Europe: retrospect and prospect, Journal of Applied Corporate Finance, $18(3), 38-55$. 


\begin{tabular}{|c|c|c|}
\hline Total assets & total assets (in Pound Sterling millions) & Worldscope \\
\hline Leverage & total debt divided by total assets & Worldscope \\
\hline $\mathrm{ROA}$ & net income divided by total assets & Worldscope \\
\hline Market to book & market capitalization plus total debt divided by total assets & Worldscope \\
\hline \multicolumn{3}{|c|}{ Market to book decomposition into } \\
\hline firm-specific error & $\begin{array}{l}\text { first component of the decomposition due to Rhodes-Kropf et } \\
\text { al. (2005) Model } 3 \text { with industries matching our specification } \\
\text { as in Table } 3 \text {, Panel A; this component measures deviation of } \\
\text { firm value from short-run industry pricing }\end{array}$ & Own estimations \\
\hline sector error & $\begin{array}{l}\text { second component of the decomposition (described in firm- } \\
\text { specific error) that measures short-run deviation from long- } \\
\text { run pricing of all firms in the same industry }\end{array}$ & Own estimations \\
\hline long-run value to book & $\begin{array}{l}\text { third component of the decomposition (described in firm- } \\
\text { specific error) that measures deviation of long-run pricing of } \\
\text { all firms in the same industry from the firm book value }\end{array}$ & Own estimations \\
\hline Rumours & $\begin{array}{l}\text { number of takeover rumours during two calendar years before } \\
\text { PtP transaction }\end{array}$ & $\begin{array}{l}\text { Lexis Nexis and SDC } \\
\text { M\&A }\end{array}$ \\
\hline Director buying & $\begin{array}{l}\text { dummy variable that is set to one in case executive directors } \\
\text { were buying shares of their own firm during January to De- } \\
\text { cember of the calendar year before PtP transaction or in the } \\
\text { previous year for the non-PtP firms and zero otherwise }\end{array}$ & Hemmington Scott \\
\hline Director selling & $\begin{array}{l}\text { dummy variable that is set to one in case executive directors } \\
\text { were selling shares of their own firm during January to De- } \\
\text { cember of the calendar year before PtP transaction or in the } \\
\text { previous year for the non-PtP firms and zero otherwise }\end{array}$ & Hemmington Scott \\
\hline Sales growth & $\begin{array}{l}\text { sales growth during } 3 \text { financial years before PtP transaction } \\
\text { average }\end{array}$ & Worldscope \\
\hline Analysts following & $\begin{array}{l}\text { number of analysts following the company in December of the } \\
\text { calender year before PtP transaction }\end{array}$ & IBES \\
\hline Thin trading & $\begin{array}{l}\text { fraction of days with zero percent return during January to } \\
\text { December of the calendar year before PtP transaction or in } \\
\text { the previous year for the non-PtP firms }\end{array}$ & Datastream \\
\hline \multicolumn{3}{|c|}{$\mathrm{C}^{1}$} \\
\hline executives & $\begin{array}{l}\text { percentage of shares held by executive directors of the com- } \\
\text { pany }\end{array}$ & Corporate Register \\
\hline non-executives & $\begin{array}{l}\text { percentage of shares held by non-executive directors of the } \\
\text { company }\end{array}$ & Corporate Register \\
\hline financial inst. & $\begin{array}{l}\text { percentage of shares held by financial institutions (e.g. pen- } \\
\text { sion funds, mutual funds, insurance companies, banks, venture } \\
\text { capitalists) }\end{array}$ & Corporate Register \\
\hline other firms & percentage of shares held by industrial firms & Corporate Register \\
\hline individuals & $\begin{array}{l}\text { percentage of shares held by persons that are not directors of } \\
\text { the company }\end{array}$ & Corporate Register \\
\hline Herfindahl index & $\begin{array}{l}\text { sum of squared equity stakes held by the individual blockhold- } \\
\text { ers }\end{array}$ & Corporate Register \\
\hline Cash & cash and marketable securities divided by total assets & Worldscope \\
\hline Excess cash & $\begin{array}{l}\text { residuals of a regression of the natural logarithm of cash over } \\
\text { net assets (total assets minus cash and marketable securities) } \\
\text { on the natural logarithm of net assets, market to book ad- } \\
\text { justed for net assets, net working capital over net assets, cap- } \\
\text { ital expenditures over net assets, R\&D over net assets, free } \\
\text { cash flow over net assets, leverage and a dividend dummy; all } \\
\text { variables are industry and time adjusted }\end{array}$ & $\begin{array}{l}\text { Own estimations } \\
\text { based on Opler et al. } \\
(1999) \text { and Dittmar } \\
\text { and } \text { Mahrt-Smith } \\
(2007)\end{array}$ \\
\hline Normal cash & fitted values of a regression as defined in excess cash above & Own estimations \\
\hline Free cash flows & $\begin{array}{l}\text { (ebitda - taxes - interest - cash dividend - stock repurchases) } \\
\text { divided by sales }\end{array}$ & Worldscope \\
\hline Investment & capital expenditures divided by sales & Worldscope \\
\hline Payout ratio & $\begin{array}{l}\text { cash dividend divided by the sum of net income and depreci- } \\
\text { ation }\end{array}$ & Worldscope \\
\hline Tax & income taxes divided by sales & Worldscope \\
\hline AIM & $\begin{array}{l}\text { dummy variable that is set to one in case the firm is listed on } \\
\text { the alternative market with lower listing requirements }\end{array}$ & Corporate Register \\
\hline
\end{tabular}


Table 2: Basic Statistics by PtP Type

\begin{tabular}{|c|c|c|c|c|c|c|c|}
\hline \multirow[b]{2}{*}{ Variable } & \multicolumn{4}{|c|}{ Means } & \multicolumn{3}{|c|}{$t$-test $p$-values } \\
\hline & $\begin{array}{c}\text { non-PtP } \\
\text { random }\end{array}$ & $\begin{array}{l}\text { non-PtP } \\
\text { matched }\end{array}$ & $\mathrm{MBO}$ & $\mathrm{PE}$ & $\begin{array}{l}\text { random } \\
\mathrm{MBO}\end{array}$ & $\begin{array}{l}\text { random } \\
\mathrm{PE}\end{array}$ & $\begin{array}{c}\mathrm{MBO} \\
\mathrm{PE} \\
\end{array}$ \\
\hline \multicolumn{8}{|l|}{$\underline{\text { Panel A }}$} \\
\hline Total assets & 706.2 & 113.1 & 53.4 & 170.5 & 0.000 & 0.000 & 0.000 \\
\hline Leverage & 0.199 & 0.187 & 0.177 & 0.186 & 0.173 & 0.223 & 0.373 \\
\hline $\mathrm{ROA}$ & -0.020 & 0.035 & -0.020 & 0.043 & 0.359 & 0.002 & 0.038 \\
\hline Market to book & 1.541 & 1.205 & 0.703 & 1.065 & 0.000 & 0.000 & 0.000 \\
\hline Rumours & 0.204 & 0.023 & 0.407 & 0.533 & 0.003 & 0.000 & 0.080 \\
\hline Sales growth & 0.155 & 0.137 & 0.121 & 0.133 & 0.268 & 0.221 & 0.422 \\
\hline Analysts following & 3.028 & 2.845 & 1.815 & 3.200 & 0.000 & 0.260 & 0.000 \\
\hline Thin trading & 0.530 & 0.603 & 0.745 & 0.564 & 0.000 & 0.058 & 0.000 \\
\hline $\begin{array}{c}\text { Ownership of } \\
\text { executives }\end{array}$ & 0.088 & 0.121 & 0.223 & 0.084 & 0.000 & 0.415 & 0.000 \\
\hline non-executives & 0.032 & 0.043 & 0.029 & 0.027 & 0.344 & 0.239 & 0.430 \\
\hline financial inst. & 0.187 & 0.209 & 0.147 & 0.304 & 0.030 & 0.000 & 0.000 \\
\hline other firms & 0.030 & 0.050 & 0.011 & 0.023 & 0.001 & 0.201 & 0.132 \\
\hline individuals & 0.124 & 0.091 & 0.177 & 0.073 & 0.035 & 0.000 & 0.001 \\
\hline Herfindahl index & 0.187 & 0.092 & 0.216 & 0.122 & 0.162 & 0.000 & 0.003 \\
\hline Cash & 0.132 & 0.129 & 0.154 & 0.085 & 0.178 & 0.000 & 0.013 \\
\hline Free cash flows & -0.089 & -0.055 & -0.181 & 0.033 & 0.228 & 0.000 & 0.047 \\
\hline Investment & 0.098 & 0.095 & 0.063 & 0.065 & 0.228 & 0.000 & 0.047 \\
\hline Payout ratio & 0.188 & 0.337 & 0.178 & 0.370 & 0.456 & 0.019 & 0.082 \\
\hline $\operatorname{Tax}$ & 0.020 & 0.022 & 0.016 & 0.022 & 0.098 & 0.215 & 0.058 \\
\hline Number of obs. & 1400 & 129 & 54 & 75 & & & \\
\hline
\end{tabular}

continued on next page 
continued from previous page

\begin{tabular}{|c|c|c|c|c|c|c|c|}
\hline \multirow[b]{2}{*}{ Variable } & \multicolumn{4}{|c|}{ Medians } & \multicolumn{3}{|c|}{$U$-test $p$-values } \\
\hline & $\begin{array}{l}\text { non-PtP } \\
\text { random }\end{array}$ & $\begin{array}{l}\text { non-PtP } \\
\text { matched }\end{array}$ & $\mathrm{MBO}$ & $\mathrm{PE}$ & $\begin{array}{c}\text { random } \\
\mathrm{MBO}\end{array}$ & $\begin{array}{c}\text { random } \\
\mathrm{PE}\end{array}$ & $\begin{array}{c}\mathrm{MBO} \\
\mathrm{PE}\end{array}$ \\
\hline
\end{tabular}

\section{$\underline{\text { Panel B }}$}

Total assets

$$
67.0
$$

$\begin{array}{ll}67.0 \quad 50.7 \\ 0.173 & 0.155\end{array}$

$39.6 \quad 66.3$

0.001

0.449

0.000

Leverage

ROA

0.173

0.155

0.146

0.178

0.103

0.461

0.196

Market to book

$0.044 \quad 0.058$

$\begin{array}{ll}0.042 & 0.071\end{array}$

0.153

0.000

0.001

Rumours

1.013

0.868

0.65

0.835

0.000

0.027

0.000

Sales growth

0

0

0

0.009

0.000

0.112

Analysts following

0.071

0.088

$0.016 \quad 0.065$

0.032

0.432

0.037

2

Thin trading

$0.571 \quad 0.621$

1

3

0.000

0.114

0.000

Ownership of

non-executives

$0.015 \quad 0.038$

$0.766 \quad 0.594$

0.000

0.346

0.000

financial inst.

$0.002 \quad 0.005$

$\begin{array}{ll}0.158 & 0.017\end{array}$

$0.000 \quad 0.078$

0.000

$0.001 \quad 0.001$

0.453

0.148

0.333

$0.151 \quad 0.180$

$0.101 \quad 0.306$

0.050

0.000

0.000

other firms

0

individuals

$\begin{array}{ll}0 & 0 \\ 0.055 & 0.036\end{array}$

$0 \quad 0$

0.083

0.183

0.334

$0.109 \quad 0.031$

0.018

0.008

0.001

$0.118 \quad 0.014$

$0.152 \quad 0.059$

0.081

0.012

0.003

Cash

$0.070 \quad 0.076$

$0.072 \quad 0.045$

0.320

0.019

0.068

Free cash flows

0.048

0.058

$0.031 \quad 0.050$

0.034

0.403

0.029

Investment

0.038

0.039

$\begin{array}{ll}0.031 & 0.038\end{array}$

0.018

0.300

0.111

Payout ratio

$0.180 \quad 0.327$

$\begin{array}{ll}0.197 & 0.235\end{array}$

0.470

0.008

0.106

0.015

0.016

$0.012 \quad 0.020$

0.077

0.193

0.028

Number of obs.

1400

129

54

75

Note: This table shows the means and medians across the random and matched samples of non-PtP firms, all PtP firms, as well as management buyouts (MBO) and private equity backed (PE backed) deals. The last three columns show $p$-values for $t$-test for equal means allowing for unequal variances in Panel A and a Mann-Whitney U-test for equal medians in Panel B. All variables are trimmed at the 1st and 99th percentiles, except for the ownership and illiquidity variables.

See Table 1 for variable definitions. 
Table 3: Multinomial Logistic Regression Analysis of Factors Influencing the Likelihood of Going Private Transactions

\begin{tabular}{|c|c|c|c|c|c|}
\hline \multirow[t]{2}{*}{ Variable } & \multicolumn{2}{|c|}{$\begin{array}{c}\text { Management } \\
\text { buyouts }\end{array}$} & \multicolumn{2}{|c|}{$\begin{array}{c}\text { Private equity } \\
\text { backed deals }\end{array}$} & \multirow{2}{*}{$\begin{array}{c}\text { LR test } \\
\text { of equal } \\
\text { parameters }\end{array}$} \\
\hline & coeff. & s.e. & coeff. & s.e. & \\
\hline
\end{tabular}

Panel A: Random sample

\begin{tabular}{|c|c|c|c|c|c|}
\hline Constant & -6.377 & $(0.305)^{* * *}$ & -5.004 & $(0.219)^{* * *}$ & \\
\hline Rumours & 1.407 & $(0.325)^{* * *}$ & 1.547 & $(0.248)^{* * *}$ & 0.722 \\
\hline Market to book & -0.833 & $(0.264)^{* * *}$ & -0.420 & $(0.195)^{* *}$ & 0.182 \\
\hline Sales growth & 0.284 & $(0.401)$ & 0.057 & $(0.385)$ & 0.674 \\
\hline $\mathrm{ROA}$ & -0.132 & $(0.720)$ & 2.131 & $(1.374)$ & 0.118 \\
\hline Ln total assets & 0.111 & $(0.159)$ & -0.198 & $(0.123)$ & 0.115 \\
\hline Cash & 1.048 & $(0.898)$ & -1.926 & $(1.147)^{*}$ & 0.031 \\
\hline Payout ratio & 0.205 & $(0.384)$ & 0.460 & $(0.317)$ & 0.600 \\
\hline Leverage & -0.465 & $(0.978)$ & -0.659 & $(0.879)$ & 0.880 \\
\hline Executive ownership & 3.220 & $(0.727)^{* * *}$ & 0.104 & $(0.952)$ & 0.005 \\
\hline Analysts following & -0.161 & $(0.084)^{*}$ & 0.046 & $(0.055)$ & 0.030 \\
\hline Thin trading & 3.562 & $(1.011)^{* * *}$ & -0.330 & $(0.797)$ & 0.002 \\
\hline $\operatorname{Tax}$ & 6.815 & $(5.812)$ & 4.463 & $(4.892)$ & 0.749 \\
\hline No heterogeneity test & \multicolumn{2}{|c|}{0.000} & \multicolumn{2}{|c|}{0.000} & 0.000 \\
\hline IIA test & \multicolumn{2}{|c|}{1.000} & \multicolumn{2}{|c|}{1.000} & \\
\hline
\end{tabular}


continued from previous page

\begin{tabular}{|c|c|c|c|c|c|}
\hline \multirow[t]{2}{*}{ Variable } & \multicolumn{2}{|c|}{$\begin{array}{c}\text { Management } \\
\text { buyouts }\end{array}$} & \multicolumn{2}{|c|}{$\begin{array}{c}\text { Private equity } \\
\text { backed deals }\end{array}$} & $\begin{array}{l}\text { LR test } \\
\text { of equal }\end{array}$ \\
\hline & coeff. & s.e. & coeff. & s.e. & parameters \\
\hline
\end{tabular}

Panel B: Matched sample

\begin{tabular}{lrlrrr}
\hline Constant & -6.529 & $(0.373)^{* * *}$ & -5.258 & $(0.269)^{* * *}$ & \\
Rumours & 4.151 & $(0.825)^{* * *}$ & 4.387 & $(0.773)^{* * *}$ & 0.618 \\
Market to book & -1.034 & $(0.414)^{* *}$ & 0.098 & $(0.262)$ & 0.006 \\
Sales growth & 0.503 & $(0.529)$ & -0.097 & $(0.605)$ & 0.352 \\
ROA & -1.009 & $(1.523)$ & 0.243 & $(1.486)$ & 0.429 \\
Cash & 2.274 & $(1.302)^{*}$ & -2.269 & $(1.647)$ & 0.006 \\
Payout ratio & -0.140 & $(0.140)$ & 0.057 & $(0.112)$ & 0.210 \\
Leverage & 0.009 & $(1.254)$ & 0.878 & $(1.216)$ & 0.553 \\
Executive ownership & 2.834 & $(1.132)^{* *}$ & -1.639 & $(1.347)$ & 0.007 \\
Analysts following & 0.005 & $(0.104)$ & 0.022 & $(0.065)$ & 0.864 \\
Thin trading & 5.810 & $(1.568)^{* * *}$ & -0.271 & $(1.072)$ & 0.000 \\
Tax & -2.694 & $(9.700)$ & -5.298 & $(8.583)$ & 0.809 \\
No heterogeneity test & \multicolumn{2}{c}{0.000} & 0.000 & 0.000 \\
IIA test & \multicolumn{2}{c}{1.000} & 1.000 & \\
\hline
\end{tabular}

Note: The table reports estimation results for the multinomial logistic regression model given in (1), using the non-PtP firms as reference group. The model is estimated using $54 \mathrm{MBOs}$ and 75 PE backed deals over the period 1997-2003. Panel A shows results with a random sample of 1400 non-PtP firms. Panel B shows results with a size- and industry-matched sample of non-PtP firms. All regressors are industry and time adjusted as they enter the multinomial logit model as deviations from the industry and year median. Standard errors are given in parentheses, with ${ }^{* * *},{ }^{* *}$, and ${ }^{*}$ indicating significance at the $1 \%, 5 \%$ and $10 \%$ level, respectively. The final column shows $p$-values for the LR test of equal parameters for the two sub-groups of PtP deals. The line "No heterogeneity test" reports $p$-values for the LR test of Cramer and Ridder (1991) that all parameters except the intercepts are equal for two groups. The first two numbers in this line compare the non-PtP group with the MBOs and PE backed deals, respectively. The line "IIA test" reports $p$-values for the Hausman and McFadden (1984) LR test for the validity of the independence of irrelevant alternatives (IIA) assumption, omitting the indicated group from the model. Variable definitions are provided in Table 1. 
Table 4: Multinomial Logistic Regression Analysis of Factors Influencing the Likelihood of Going Private Transactions (Sensitivity Checks I)

\begin{tabular}{|c|c|c|c|c|c|}
\hline \multirow[t]{2}{*}{ Variable } & \multicolumn{2}{|c|}{$\begin{array}{c}\text { Management } \\
\text { buyouts }\end{array}$} & \multicolumn{2}{|c|}{$\begin{array}{c}\text { Private equity } \\
\text { backed deals }\end{array}$} & \multirow{2}{*}{$\begin{array}{c}\text { LR test } \\
\text { of equal } \\
\text { parameters }\end{array}$} \\
\hline & coeff. & s.e. & coeff. & s.e. & \\
\hline Constant & -6.762 & $(0.374)^{* * *}$ & -5.249 & $(0.258)^{* * *}$ & \\
\hline Rumours & 1.236 & $(0.329)^{* * *}$ & 1.548 & $(0.256)^{* * *}$ & 0.436 \\
\hline Firm-specific error & -0.720 & $(0.248)^{* * *}$ & -0.877 & $(0.221)^{* * *}$ & 0.471 \\
\hline Sector error & -1.406 & $(0.755)^{*}$ & 0.429 & $(0.760)$ & 0.078 \\
\hline Long-run value to book & -0.888 & $(0.273)^{* * *}$ & -0.040 & $(0.232)$ & 0.011 \\
\hline Director buying & 0.149 & $(0.321)$ & -0.200 & $(0.271)$ & 0.393 \\
\hline Director selling & -0.999 & $(0.624)^{*}$ & 0.293 & $(0.327)$ & 0.042 \\
\hline Sales growth & 0.455 & $(0.413)$ & 0.088 & $(0.376)$ & 0.500 \\
\hline $\mathrm{ROA}$ & 0.117 & $(0.791)$ & 1.478 & $(1.162)$ & 0.307 \\
\hline Ln total assets & 0.173 & $(0.154)$ & -0.202 & $(0.121)^{*}$ & 0.050 \\
\hline Cash & 1.340 & $(0.958)$ & -2.329 & $(1.199)^{*}$ & 0.010 \\
\hline Payout ratio & 0.326 & $(0.387)$ & 0.648 & $(0.342)^{*}$ & 0.521 \\
\hline Leverage & -1.793 & $(1.424)$ & 0.676 & $(1.064)$ & 0.144 \\
\hline Executive ownership & 3.101 & $(0.737)^{* * *}$ & 0.284 & $(0.963)$ & 0.012 \\
\hline Analysts following & -0.177 & $(0.089)^{* *}$ & 0.036 & $(0.057)$ & 0.033 \\
\hline Thin trading & 4.132 & $(0.978)^{* * *}$ & -0.502 & $(0.792)$ & 0.000 \\
\hline Tax & 9.330 & $(6.043)$ & 6.614 & $(4.927)$ & 0.719 \\
\hline No heterogeneity test & \multicolumn{2}{|c|}{0.000} & \multicolumn{2}{|c|}{0.000} & 0.000 \\
\hline IIA test & \multicolumn{2}{|c|}{1.000} & \multicolumn{2}{|c|}{1.000} & \\
\hline
\end{tabular}

Note: The table reports estimation results for the multinomial logistic regression model given in (1), using a random sample of 1400 non-PtP firms as reference group. The model is estimated using 54 MBOs and 75 PE backed deals over the period 1997-2003. All regressors are industry and time adjusted as they enter the multinomial logit model as deviations from the industry and year median. Standard errors are given in parentheses, with ${ }^{* * *},{ }^{* *}$, and ${ }^{*}$ indicating significance at the $1 \%, 5 \%$ and $10 \%$ level, respectively. The final column shows $p$-values for the LR test of equal parameters for the two sub-groups of PtP deals. The line "No heterogeneity test" reports $p$-values for the LR test of Cramer and Ridder (1991) that all parameters except the intercepts are equal for two groups. The first two numbers in this line compare the non-PtP group with the MBOs and PE backed deals, respectively. The line "IIA test" reports $p$-values for the Hausman and McFadden (1984) LR test for the validity of the independence of irrelevant alternatives (IIA) assumption, omitting the indicated group from the model. Variable definitions are provided in Table 1. 
Table 5: Multinomial Logistic Regression Analysis of Factors Influencing the Likelihood of Going Private Transactions (Sensitivity Checks II)

\begin{tabular}{|c|c|c|c|c|c|}
\hline \multirow[t]{2}{*}{ Variable } & \multicolumn{2}{|c|}{$\begin{array}{c}\text { Management } \\
\text { buyouts }\end{array}$} & \multicolumn{2}{|c|}{$\begin{array}{l}\text { Private equity } \\
\text { backed deals }\end{array}$} & \multirow{2}{*}{$\begin{array}{c}\text { LR test } \\
\text { of equal } \\
\text { parameters }\end{array}$} \\
\hline & coeff. & s.e. & coeff. & s.e. & \\
\hline Constant & -6.172 & $(0.286)^{* * *}$ & -5.013 & $(0.218)^{* * *}$ & \\
\hline Rumours & 1.357 & $(0.320)^{* * *}$ & 1.549 & $(0.247)^{* * *}$ & 0.620 \\
\hline Market to book & -1.215 & $(0.260)^{* * *}$ & -0.383 & $(0.180)^{* *}$ & 0.006 \\
\hline Sales growth & 0.171 & $(0.393)$ & 0.056 & $(0.384)$ & 0.834 \\
\hline $\mathrm{ROA}$ & -0.054 & $(0.698)$ & 2.151 & $(1.378)$ & 0.125 \\
\hline Ln total assets & -0.260 & $(0.116)^{* *}$ & -0.161 & $(0.085)^{*}$ & 0.476 \\
\hline Cash & 1.116 & $(0.871)$ & -1.889 & $(1.142)^{*}$ & 0.027 \\
\hline Payout ratio & 0.203 & $(0.362)$ & 0.469 & $(0.318)$ & 0.570 \\
\hline Leverage & 0.045 & $(0.948)$ & -0.686 & $(0.876)$ & 0.561 \\
\hline Executive ownership & 3.256 & $(0.723)^{* * *}$ & 0.127 & $(0.949)$ & 0.004 \\
\hline Analysts following & -0.164 & $(0.085)^{*}$ & 0.047 & $(0.055)$ & 0.027 \\
\hline Tax & 6.794 & $(5.736)$ & 4.300 & $(4.899)$ & 0.733 \\
\hline No heterogeneity test & \multicolumn{2}{|c|}{0.000} & \multicolumn{2}{|c|}{0.000} & 0.000 \\
\hline IIA test & \multicolumn{2}{|c|}{1.000} & \multicolumn{2}{|c|}{1.000} & \\
\hline
\end{tabular}

Note: The table reports estimation results for the multinomial logistic regression model given in (1), using a random sample of 1400 non-PtP firms as reference group. The model is estimated using $54 \mathrm{MBOs}$ and $75 \mathrm{PE}$ backed deals over the period 1997-2003. All regressors are industry and time adjusted as they enter the multinomial logit model as deviations from the industry and year median. Standard errors are given in parentheses, with ${ }^{* * *},{ }^{* *}$, and ${ }^{*}$ indicating significance at the $1 \%, 5 \%$ and $10 \%$ level, respectively. The final column shows $p$-values for the LR test of equal parameters for the two sub-groups of PtP deals. The line "No heterogeneity test" reports $p$-values for the LR test of Cramer and Ridder (1991) that all parameters except the intercepts are equal for two groups. The first two numbers in this line compare the nonPtP group with the MBOs and PE backed deals, respectively. The line "IIA test" reports $p$-values for the Hausman and McFadden (1984) LR test for the validity of the independence of irrelevant alternatives (IIA) assumption, omitting the indicated group from the model. Variable definitions are provided in Table 1. 
Table 6: Multinomial Logistic Regression Analysis of Factors Influencing the Likelihood of Going Private Transactions (Sensitivity Checks III)

\begin{tabular}{|c|c|c|c|c|c|}
\hline \multirow[t]{2}{*}{ Variable } & \multicolumn{2}{|c|}{$\begin{array}{c}\text { Management } \\
\text { buyouts }\end{array}$} & \multicolumn{2}{|c|}{$\begin{array}{l}\text { Private equity } \\
\text { backed deals }\end{array}$} & \multirow{2}{*}{$\begin{array}{c}\text { LR test } \\
\text { of equal } \\
\text { parameters }\end{array}$} \\
\hline & coeff. & s.e. & coeff. & s.e. & \\
\hline Constant & -6.134 & $(0.321)^{* * *}$ & -5.783 & $(0.341)^{* * *}$ & \\
\hline Rumours & 1.298 & $(0.424)^{* * *}$ & 1.547 & $(0.280)^{* * *}$ & 0.564 \\
\hline Market to book & -0.981 & $(0.300)^{* * *}$ & -0.381 & $(0.220)^{*}$ & 0.094 \\
\hline Sales growth & 0.310 & $(0.398)$ & 0.346 & $(0.373)$ & 0.944 \\
\hline $\mathrm{ROA}$ & -0.220 & $(0.774)$ & 0.364 & $(1.188)$ & 0.670 \\
\hline Ln total assets & 0.003 & $(0.170)$ & -0.103 & $(0.137)$ & 0. 617 \\
\hline Excess cash & 0.542 & $(0.328)^{*}$ & -0.734 & $(0.616)$ & 0.042 \\
\hline Normal cash & -0.007 & $(0.094)$ & -0.062 & $(0.081)$ & 0.642 \\
\hline Free cash flow & 0.060 & $(0.236)$ & 0.056 & $(0.448)$ & 0.993 \\
\hline Payout ratio & 0.169 & $(0.380)$ & 0.523 & $(0.327)$ & 0.472 \\
\hline Leverage & 0.728 & $(1.251)$ & -1.198 & $(1.515)$ & 0.310 \\
\hline Executive ownership & 3.204 & $(0.792)^{* * *}$ & 0.800 & $(1.017)$ & 0.043 \\
\hline Analysts following & -0.146 & $(0.090)^{*}$ & 0.031 & $(0.062)$ & 0.088 \\
\hline Thin trading & 3.060 & $(1.092)^{* * *}$ & -0.159 & $(0.887)$ & 0.018 \\
\hline Tax & 7.173 & $(6.270)$ & 6.997 & $(5.375)$ & 0.983 \\
\hline No heterogeneity test & \multicolumn{2}{|c|}{0.000} & \multicolumn{2}{|c|}{0.000} & 0.000 \\
\hline IIA test & \multicolumn{2}{|c|}{1.000} & \multicolumn{2}{|c|}{1.000} & \\
\hline
\end{tabular}

Note: The table reports estimation results for the multinomial logistic regression model given in (1), using a random sample of 1400 non-PtP firms as reference group. The model is estimated using $54 \mathrm{MBOs}$ and $75 \mathrm{PE}$ backed deals over the period 1997-2003. All regressors are industry and time adjusted as they enter the multinomial logit model as deviations from the industry and year median. Standard errors are given in parentheses, with ${ }^{* * *},{ }^{* *}$, and ${ }^{*}$ indicating significance at the $1 \%, 5 \%$ and $10 \%$ level, respectively. The final column shows $p$-values for the LR test of equal parameters for the two sub-groups of PtP deals. The line "No heterogeneity test" reports $p$-values for the LR test of Cramer and Ridder (1991) that all parameters except the intercepts are equal for two groups. The first two numbers in this line compare the nonPtP group with the MBOs and PE backed deals, respectively. The line "IIA test" reports $p$-values for the Hausman and McFadden (1984) LR test for the validity of the independence of irrelevant alternatives (IIA) assumption, omitting the indicated group from the model. Variable definitions are provided in Table 1. 
Table 7: Summary Statistics of Firms Grouped by Size

\begin{tabular}{lrcccccc}
\hline \hline & \multicolumn{7}{c}{ Mean by deciles of size } \\
\cline { 2 - 7 } Decile & \multicolumn{1}{c}{ Size } & $\mathrm{PtP}(\%)$ & $\mathrm{MBO}(\%)$ & $\mathrm{PE}(\%)$ & $\begin{array}{c}\text { Thin } \\
\text { trading }\end{array}$ & $\begin{array}{c}\text { Analysts } \\
\text { following }\end{array}$ & AIM \\
\hline 1 (small) & 3.97 & 3.3 & 2.0 & 1.3 & 0.80 & 1.79 & 0.10 \\
2 & 11.86 & 9.8 & 5.2 & 4.6 & 0.72 & 2.07 & 0.16 \\
3 & 20.55 & 9.2 & 5.9 & 3.3 & 0.69 & 1.97 & 0.09 \\
4 & 33.88 & 11.1 & 4.6 & 6.5 & 0.66 & 2.22 & 0.10 \\
5 & 52.08 & 15.7 & 7.8 & 7.8 & 0.59 & 2.75 & 0.08 \\
6 & 81.61 & 13.7 & 5.9 & 7.8 & 0.59 & 3.37 & 0.12 \\
7 & 136.85 & 7.8 & 2.6 & 5.2 & 0.53 & 3.33 & 0.14 \\
8 & 261.43 & 7.8 & 1.3 & 6.5 & 0.46 & 3.63 & 0.11 \\
9 & 749.28 & 5.9 & 0.0 & 5.9 & 0.27 & 4.42 & 0.12 \\
10 (large) & 7170.42 & 0.0 & 0.0 & 0.0 & 0.10 & 4.34 & 0.14 \\
Total & 856.32 & 8.4 & 3.5 & 4.9 & 0.54 & 2.99 & 0.12 \\
\hline
\end{tabular}

Note: The table reports mean values of several variables across size deciles where size is measured by total assets. Variable definitions are provided in Table 1. 
Table 8: Summary Statistics of Firms Grouped by Size

\begin{tabular}{|c|c|c|c|c|}
\hline \multirow[b]{2}{*}{ Decile } & \multicolumn{4}{|c|}{ Mean by deciles of size } \\
\hline & Size & $\begin{array}{l}\text { Thin } \\
\text { trading }\end{array}$ & $\begin{array}{l}\text { Analysts } \\
\text { following }\end{array}$ & AIM \\
\hline \multicolumn{5}{|c|}{ Panel A: Non-PtP firms } \\
\hline 1 (small) & 4.09 & 0.79 & 1.79 & 0.15 \\
\hline 2 & 12.32 & 0.72 & 2.10 & 0.15 \\
\hline 3 & 21.49 & 0.68 & 2.03 & 0.09 \\
\hline 4 & 34.97 & 0.66 & 2.25 & 0.11 \\
\hline 5 & 53.42 & 0.57 & 2.95 & 0.06 \\
\hline 6 & 84.80 & 0.58 & 3.41 & 0.13 \\
\hline 7 & 141.75 & 0.53 & 3.36 & 0.13 \\
\hline 8 & 268.83 & 0.45 & 3.62 & 0.11 \\
\hline 9 & 734.29 & 0.27 & 4.39 & 0.12 \\
\hline 10 (large) & 7020.87 & 0.10 & 4.35 & 0.13 \\
\hline \multicolumn{5}{|c|}{ Panel B: Private-equity backed PtP deals } \\
\hline 1 (small) & 4.40 & 0.71 & 2.50 & 0.00 \\
\hline 2 & 11.67 & 0.70 & 2.57 & 0.28 \\
\hline 3 & 18.64 & 0.69 & 2.40 & 0.00 \\
\hline 4 & 35.45 & 0.61 & 2.70 & 0.00 \\
\hline 5 & 53.79 & 0.50 & 2.58 & 0.17 \\
\hline 6 & 80.79 & 0.60 & 3.00 & 0.08 \\
\hline 7 & 132.52 & 0.65 & 3.00 & 0.13 \\
\hline 8 & 264.90 & 0.46 & 4.50 & 0.20 \\
\hline 9 & 789.61 & 0.39 & 4.67 & 0.22 \\
\hline 10 (large) & -- & -- & -- & -- \\
\hline \multicolumn{5}{|c|}{ Panel C: Management buyouts } \\
\hline 1 (small) & 4.42 & 0.92 & 0.67 & 0.33 \\
\hline 2 & 11.49 & 0.77 & 1.25 & 0.12 \\
\hline 3 & 19.18 & 0.79 & 0.89 & 0.00 \\
\hline 4 & 31.44 & 0.79 & 2.29 & 0.14 \\
\hline 5 & 52.20 & 0.74 & 2.33 & 0.08 \\
\hline 6 & 81.22 & 0.71 & 2.44 & 0.11 \\
\hline 7 & 150.52 & 0.56 & 2.00 & 0.00 \\
\hline 8 & 207.21 & 0.60 & 2.00 & 0.00 \\
\hline 9 & -- & -- & -- & -- \\
\hline 10 (large) & -- & -- & -- & -- \\
\hline
\end{tabular}

Note: The table reports mean values of thin trading, analysts following and frequency of AIM listing across size deciles for the non-PtP firms (Panel A), management buyouts (Panel B), and private equity backed $\mathrm{PtP}$ deals (Panel C). Size is measured by total assets. Variable definitions are provided in Table 1. 


\section{Publications in the Report Series Research ${ }^{*}$ in Management}

\section{ERIM Research Program: "Finance and Accounting"}

2007

Revisiting Uncovered Interest Rate Parity: Switching Between UIP and the Random Walk

Ronald Huisman and Ronald Mahieu

ERS-2007-001-F\&A

http://hdl.handle.net/1765/8288

Hourly Electricity Prices in Day-Ahead Markets

Ronald Huisman, Christian Huurman and Ronald Mahieu

ERS-2007-002-F\&A

http://hdl.handle.net/1765/8289

Do Exchange Rates Move in Line with Uncovered Interest Parity?

Ronald Huisman, Ronald Mahieu and Arjen Mulder

ERS-2007-012-F\&A

http://hdl.handle.net/1765/8993

Hedging Exposure to Electricity Price Risk in a Value at Risk Framework

Ronald Huisman, Ronald Mahieu and Felix Schlichter

ERS-2007-013-F\&A

http://hdl.handle.net/1765/8995

Corporate Governance and Acquisitions: Acquirer Wealth Effects in the Netherlands

Abe de Jong, Marieke van der Poel and Michiel Wolfswinkel

ERS-2007-016-F\&A

$\underline{\text { http://hdl.handle.net/1765/9403 }}$

The Effect of Monetary Policy on Exchange Rates during Currency Crises; The Role of Debt, Institutions and Financial Openness

Sylvester C.W. Eijffinger and Benedikt Goderis

ERS-2007-022-F\&A

http://hdl.handle.net/1765/9725

Do Private Equity Investors Take Firms Private for Different Reasons?

Jana P. Fidrmuc, Peter Roosenboom and Dick van Dijk

ERS-2007-028-F\&A

http://hdl.handle.net/1765/10070

The Influence of Temperature on Spike Probability in Day-Ahead Power Prices

Ronald Huisman

ERS-2007-039-F\&A

http://hdl.handle.net/1765/10179

Costs and Recovery Rates in the Dutch Liquidation-Based Bankruptcy System

Oscar Couwenberg and Abe de Jong

ERS-2007-041-F\&A

http://hdl.handle.net/1765/10461

The Volatility Effect: Lower Risk without Lower Return

David C. Blitz and Pim van Vliet

ERS-2007-044-F\&A

http://hdl.handle.net/1765/10460 
Strategic Debt: Evidence from Bertrand and Cournot Competition

Abe de Jong, Thuy Thu Nguyen and Mathijs A. van Dijk

ERS-2007-057-F\&A

http://hdl.handle.net/1765/10504

Capital Structure Around the World: The Roles of Firm- and Country-Specific Determinants

Abe de Jong, Rezaul Kabir and Thuy Thu Nguyen

ERS-2007-058-F\&A

http://hdl.handle.net/1765/10517

The Effects of Federal Funds Target Rate Changes on S\&P100 Stock Returns, Volatilities, and Correlations Helena Chulia-Soler, Martin Martens and Dick van Dijk ERS-2007-066-F\&A

http://hdl.handle.net/1765/10610

Industry Valuation Driven Earnings Management

Tao Jiao, Gerard Mertens and Peter Roosenboom

ERS-2007-069-F\&A

http://hdl.handle.net/1765/10608

The Impact of Media Attention on the Use of Alternative Earnings Measures

Miriam Koning, Gerard Mertens and Peter Roosenboom

ERS-2007-073-F\&A

http://hdl.handle.net/1765/10609

Irving Fisher and the UIP Puzzle: Meeting the Expectations a Century Later

Rachel A. Campbell, Kees G. Koedijk, James R. Lothian and Ronald J. Mahieu

ERS-2007-088-F\&A

http://hdl.handle.net/1765/10774

Electricity Portfolio Management: Optimal Peak / Off-Peak Allocations

Ronald Huisman, Ronald J. Mahieu and Felix Schlichter

ERS-2007-089-F\&A

http://hdl.handle.net/1765/10775

The Economic Value of Fundamental and Technical Information in Emerging Currency Markets

Gerben de Zwart, Thijs Markwat, Laurens Swinkels and Dick van Dijk

ERS-2007-096-F\&A

http://hdl.handle.net/1765/10891

A Recommitment Strategy for Long Term Private Equity Fund Investors

Gerben de Zwart, Brian Frieser and Dick van Dijk

ERS-2007-097-F\&A

http://hdl.handle.net/1765/10892

* A complete overview of the ERIM Report Series Research in Management: https://ep.eur.nl/handle/1765/1

ERIM Research Programs:

LIS Business Processes, Logistics and Information Systems

ORG Organizing for Performance

MKT Marketing

F\&A Finance and Accounting

STR Strategy and Entrepreneurship 